\title{
A Decision Support System on Employee Assessment Using Analytical Network Process (ANP) and BARS Methods
}

\author{
I Made Dwi Putra Asana1, I Gede Iwan Sudipa*2 ,Kadek Ari Prayoga Putra \\ 1,2,3Informatics Departement, STMIK STIKOM Indonesia, Jl. Tukad Pakerisan No.97, Kota Denpasar, Bali 80225, \\ Indonesia \\ Email: iwansudipa@stiki-indonesia.ac.id \\ * corresponding author
}

\section{A R T I C L E I N F O}

\section{Article history:}

Received: Nov 30, 2020

Revised: Dec 05, 2020

Accepted: Mar 12, 2021

Available online: Mar 30, 2021

Keywords:

Decision Support System;

Employee Assessment;

Reward;

Bonuses;

Analytical Network Process;

Rating Scale.

\section{A B S T R A C T}

Employee assessment is needed in evaluating performance and granting rewards to employees. PT. Kupu-Kupu Taman Lestari conducts an employee performance appraisal using Microsoft Excel. The growth of employee data and assessment variables resulted in the calculation method that was carried out could not provide employee ranking information quickly. The application of Microsoft Excel in processing employee valuation data has weaknesses in data documentation. The purpose of this study is the company has a website-based decision support system that makes it easy for companies to get employee performance appraisal information. The employee performance data ranking method used is the Analytical Network Process (ANP) and the performance evaluation criteria are prepared based on the Behaviorally Anchor Rating Scale (BARS) approach. BARS is used in determining criteria along with a scale of behavior that represents the performance of each criterion. ANP is used to process data of importance between criteria so that it can produce criteria weights based on a comparison between criteria. The results of this study are website-based decision support systems that can be accessed by company management via a web browser. System testing is built based on testing manual calculations with the system and testing the user's system according to the McCall model. The system calculation test shows that the system has produced the same calculation value as the manual calculation. System user testing shows that the system built meets user needs, displays information according to user input correctly, is safe from unauthorized parties, and the system is easy to use.

(C) 2021 JTI C.I.T. All rights reserved.

\section{Introduction}

Human Resources (HR) is a crucial aspect of the progress and development of a company. In essence, HR is employed in an organization as a person who moves, thinks and plans to achieve the company goals[1]. Good service and performance are the main supporting factors that are very important in business processes[2][3]. As well as the service and performance of Human Resources (HR), especially for the employees. PT. Kupu Kupu Taman Lestari is a recreational park that preserves various kinds of butterflies, which is located on Jl. Batukaru, Sandan Lebah Hamlet, Sesandan Village Tabanan, Bali. The park also exhibits various types of insects such as beetles, grasshoppers, tarantulas and scorpions.

Human resource management at PT. Kupu-Kupu Taman Lestari is done through employee assessment. It can help the company to evaluate the performance of the employees individually[4][5]. Employee assessment can also be used as information to analyze and identify employee needs and provide rewards for employees who contribute more to the company[6][7]. Therefore, it can develop 
the motivation of employees at PT. Kupu-Kupu Taman Lestari. One of the HR management systems for employee assessment is the Decision Support System.

Employee performance appraisal at PT. Kupu-Kupu Taman Lestari is done every three months. Assessment data processing using Microsoft Excel. The assessment process has not been able to provide direct employee performance ranking recommendations[8]. The number of employees that reach 40 people makes it difficult for managers to process data with the Microsoft Excel. Apart from the large amount of data that must be calculated, it is also difficult for managers to compare assessment histories for each employee because data is stored in many excel files and sheets[9]. Therefore, we need a decision support system that can make it easier for managers to produce employee performance rankings and assessment history that can be accessed at any time[10].

Several discussions regarding the employee appraisal decision support system have been carried out by [11]. This study concluded that the priority weights of the 5 criteria and 15 assessment subcriteria were generated using the Analytical Network Process (ANP) method, employee appraisal using the Rating Scale with a value of $1-5$. Subsequent research by [12] concluded that the Rating Scale is a simple technique in providing performance appraisals for each employee. A comparative study of the AHP and ANP methods conducted by concluded that the criteria weights generated by the two methods were almost the same, but the results of the priority weights for the main criteria were different because the ANP method calculates the weight based on the weight of the relationship between each criterion and the supermatrix calculation stage. Research using the BARS method in determining the criteria for employee appraisal by[13][14] in this study concluded that the BARS method is considered very effective in supporting human resource improvement strategies. Another study discussing performance measurement using the AHP and ANP methods concluded that the ANP method can extend the functionality of the AHP method in solving multi-criteria problems involving interdependent or related criteria relationships[15].

\section{Research Method}

The decision support system proposed in this study was built based website and used a relational database management system MySQL. System development phase through two stages: the stage of weight calculation priority criteria and the stage of the calculation process of employee performance appraisal. 


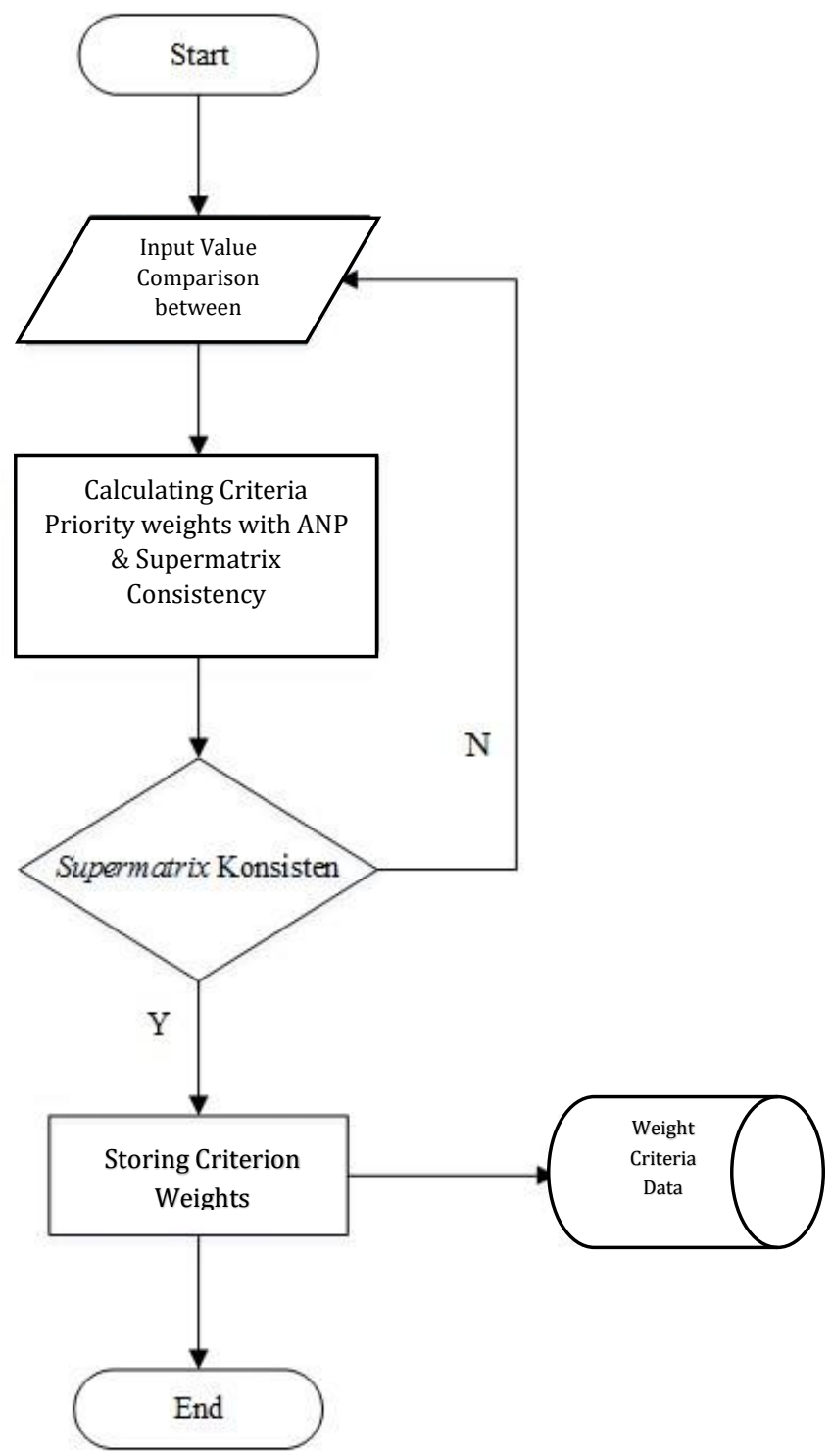

Fig 1. Criteria Weighting Flowchart

Figure 1 shows the flow of data formation criteria weights priority. The user enters the pairwise comparison score between the criteria and the system calculates the consistency score of the supermatrix. If the score generated by the system is in accordance with the standard score of the consistency ratio, then the criteria weights priority score is stored in the criteria weight data. Criteria weight data is used in the calculation of employee performance appraisal.

Table 5

Employee Assessment Criteria

\begin{tabular}{ll}
\hline No & Criteria \\
\hline C1 & Attendance \\
C2 & Service \\
C3 & Activeness \\
C4 & Cooperation \\
C5 & Emotion Control \\
\hline
\end{tabular}


At the stage of calculating the criteria weight, the criteria used are based on the BARS method approach. The BARS criterion were formed based on the policies that have been applied to the PT. KupuKupu Taman Lestari. The assessment criteria refer to the company, such as, Attendance (C1), Service (C2), Activeness (C3), Cooperation (C4), and Emotional Control (C5), which can be shown in Table 5.

Table 6

\begin{tabular}{ll}
\multicolumn{2}{l}{ The interrelationship of network elements } \\
\hline No & Network \\
\hline C1 & C1,C3 \\
C2 & C2,C3,C4 \\
C3 & C1,C3,C4 \\
C4 & C2,C3,C4 \\
C5 & C5 \\
Alternatif & C1,C2,C3,C4,C5 \\
\hline
\end{tabular}

Table 6 shows the interrelationships and interplays between the elements in the calculation of the decision support system that is built.

Table 7

Unweighted supermatrix weight calculation

\begin{tabular}{lllllll}
\hline Criteria (C) & C1 & C2 & C3 & C4 & C5 & Eigen Vector \\
\hline C1 & 1,00 & 0,00 & 0,33 & 0,00 & 0,00 & 0,06 \\
C2 & 0,00 & 1,00 & 3,00 & 3,00 & 0,00 & 0,38 \\
C3 & 3,00 & 0,00 & 1,00 & 1,00 & 0,00 & 0,23 \\
C4 & 0,00 & 0,33 & 1,00 & 1,00 & 0,00 & 0,13 \\
C5 & 0,00 & 0,00 & 0,00 & 0,00 & 1,00 & 0,20 \\
Total & 4,00 & 1,33 & 5,33 & 5,00 & 1,00 & 1,00 \\
\hline
\end{tabular}

Weight calculation begins with the weighting calculation priority Unweight Supermatrix, shown in Table 7. Eigen Vector calculated by a formula in formula 1.

The next stage is to determine the weighted matrix by multiplying all the elements in the unweighted matrix by the scores contained in the matrix cluster, the weighted matrix is shown in Table 8.

Table 8

Weighted supermatrix weight calculation

\begin{tabular}{lllllll}
\hline Criteria (C). & C1 & C2 & C3 & C4 & C5 & Eigen Vector \\
\hline C1 & 1,12 & 0,00 & 0,37 & 0,00 & 0,00 & 0,06 \\
C2 & 0,00 & 1,12 & 3,36 & 3,36 & 0,00 & 0,38 \\
C3 & 3,00 & 0,00 & 1,12 & 1,12 & 0,00 & 0,23 \\
C4 & 0,00 & 0,33 & 1,12 & 1,12 & 0,00 & 0,13 \\
C5 & 0,00 & 0,00 & 0,00 & 0,00 & 1,12 & 0,20 \\
Total & 4,12 & 1,45 & 5,97 & 5,60 & 1,12 & 1 \\
\hline
\end{tabular}

The stage after the weighted matrix is to calculate the limiting supermatrix, at this stage it will produce an eigenvector that is used as the weight value for each criterion. Limiting Supermatrix is shown in Table 9.

Table 9

Limiting supermatrix weight calculation

\begin{tabular}{lllllll}
\hline Criteria (C). & C1 & C2 & C3 & C4 & C5 & Eigen Vector \\
\hline C1 & 3,48 & 0,00 & 0,37 & 0,00 & 0,00 & $\mathbf{0 , 1 0}$ \\
C2 & 0,00 & 3,48 & 3,36 & 3,36 & 0,00 & $\mathbf{0 , 3 3}$ \\
C3 & 3,00 & 0,00 & 3,48 & 3,48 & 0,00 & $\mathbf{0 , 2 3}$ \\
C4 & 0,00 & 0,33 & 3,48 & 3,48 & 0,00 & $\mathbf{0 , 1 3}$ \\
C5 & 0,00 & 0,00 & 0,00 & 0,00 & 3,48 & $\mathbf{0 , 2 0}$ \\
Total & $\mathbf{6 , 8 4}$ & $\mathbf{3 , 4 8}$ & $\mathbf{1 0 , 3 2}$ & $\mathbf{1 0 , 3 2}$ & $\mathbf{3 , 4 8}$ & $\mathbf{0 , 9 9}$ \\
\hline
\end{tabular}

A Decision Support System on Employee Assessment Using Analytical Network Process (ANP) and BARS Methods (I Made Dwi Putra Asana, at all) 
Calculation details determine the eigenvector in the limiting supermatrix stage:

- Attendance Priority Weights (C1):

$$
\frac{\left(\left(\frac{3.48}{6.84}\right)+\left(\frac{0.00}{3.48}\right)+\left(\frac{0.00}{10.32}\right)+\left(\frac{0.00}{10.32}\right)+\left(\frac{0.00}{3.48}\right)\right)}{\left(\frac{1}{5}\right)}=0.10
$$

- Service Priority Weights:

$$
\frac{\left(\left(\frac{0.00}{6.84}\right)+\left(\frac{3.48}{3.48}\right)+\left(\frac{3.36}{10.32}\right)+\left(\frac{3.36}{10.32}\right)+\left(\frac{0.00}{3.48}\right)\right)}{\left(\frac{1}{5}\right)}=0.33
$$

- Activeness Priority Weights :

$$
\frac{\left(\left(\frac{3.36}{6.84}\right)+\left(\frac{0.00}{3.48}\right)+\left(\frac{3.48}{10.32}\right)+\left(\frac{3.48}{10.32}\right)+\left(\frac{0.00}{3.48}\right)\right)}{\left(\frac{1}{5}\right)}=0.23
$$

- Cooperation Priority Weights :

$$
\frac{\left(\left(\frac{0.00}{6.48}\right)+\left(\frac{0.00}{3.48}\right)+\left(\frac{3.48}{10.32}\right)+\left(\frac{3.48}{10.32}\right)+\left(\frac{0.00}{3.48}\right)\right)}{(1)}=0.13
$$

- Emotional Control Priority Weights:

$$
\frac{\left(\left(\frac{0.00}{6.48}\right)+\left(\frac{0.00}{3.48}\right)+\left(\frac{0.00}{10.32}\right)+\left(\frac{0.00}{10.32}\right)+\left(\frac{3.48}{3.48}\right)\right)}{\left(\frac{1}{5}\right)}=0.20
$$

Determine the $\lambda \max$ score:

$$
(6,84 * 0,10)+(3,48 * 0,33)+(10,32 * 0,23)+(10,32 * 0,13)+(3,48 * 10,20)=6,34
$$

Determine the Consistency Index CI value (Equation1) :

$C I=\frac{6,34-5}{5-1}=0,33$

Determine the Consistency Ratio CR value (Equation 2):

Due to the number of criteria are 5 criterion, the Random Index (RI) value used is 1.12 according to table 3.

$$
C R=\frac{0,33}{1,12}=0,30
$$

After the consistency ratio score is obtained, then the next eigenvector calculation results at the limiting supermatrix stage can be used as the criteria weight, it can be shown in Table 10. 
Table 10

Priority Weight Calculation Results

\begin{tabular}{lll}
\hline No. & Criteria & Criteria Weights \\
\hline 1 & Attendance & 0.10 \\
2 & Service & 0.33 \\
3 & Activeness & 0.23 \\
4 & Cooperation & 0.13 \\
5 & Emotional Control & 0.20 \\
\hline
\end{tabular}

The data in Table 10 is implemented in the system to determine the criteria weights based on the ANP method calculation, the criteria weight score are stored in the system. Furthermore, to assess the performance of each employee, the user determines the appropriate criteria anchor based on the BARS method for each employee assessment. Figure 2 shows a flowchart for calculating employee performance appraisal.

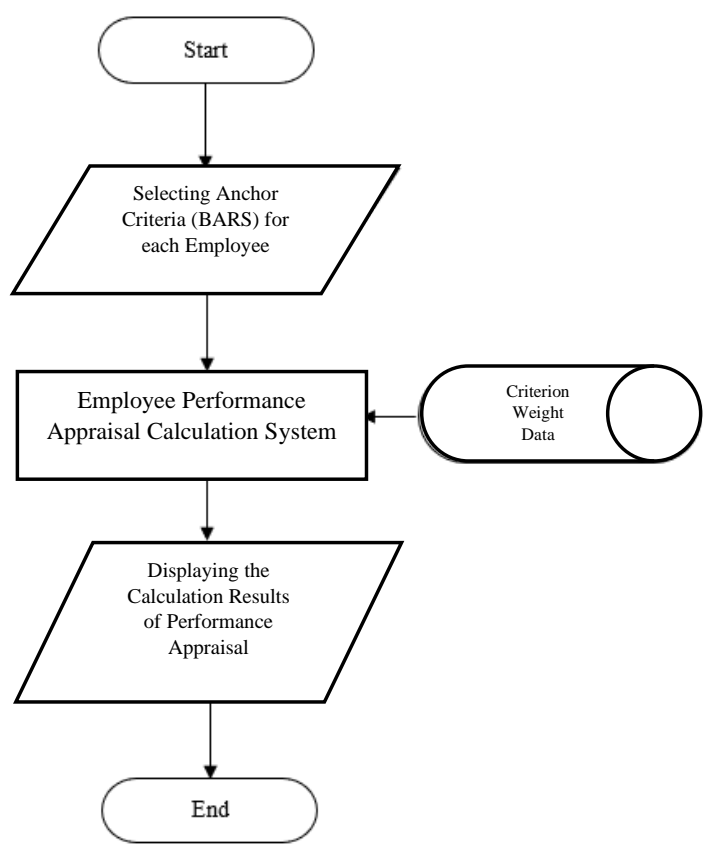

Fig 2. Performance Appraisal Calculation Flowchart

The anchors of employee performance appraisal are prepared as a reference for the process of calculating employee performance based on the appraisal criteria in Table 10, in this study the anchor used for each criterion are 5 anchors. The anchor selected in Figure 2 is a behavior that shows performance for each criterion that has been determined by the BARS approach. Table 11 shows the anchor rating scale for Attendance criteria (C1) to determine the percentage of employee attendance.

Table 11

Attendance performance rating scale

\begin{tabular}{ccl}
\hline Criteria & Scale & \multicolumn{1}{c}{ Keterangan } \\
\hline & 1 & Attendance rate over 50\% \\
Attendance & 2 & Attendance rate over 30\% \\
& 3 & Attendance rate over 15\% \\
& 4 & Attendance rate below $5 \%$ \\
& 5 & Attendance rate 0\% \\
\hline
\end{tabular}

The anchor rating scale for service criteria is intended to determine customer response to the employee concerned, shown in Table 12.

A Decision Support System on Employee Assessment Using Analytical Network Process (ANP) and BARS Methods 
Table 12

Service criteria rating scale

\begin{tabular}{ccl}
\hline Criteria & Scale & \multicolumn{1}{c}{ Information } \\
\hline \multirow{3}{*}{ Service } & 1 & There are 10 or more complaints from visitors \\
& 2 & There are 5 or more complaints from visitors \\
& 3 & There are 3 or more complaints from visitors \\
& 4 & There are 1 to 2 complaints from visitors \\
& 5 & No complaint from visitors \\
\hline
\end{tabular}

The anchor rating scale for the activeness criteria is intended to determine employee compliance with the regulations in the company, shown in Table 13.

Table 13

Activeness rating scale

\begin{tabular}{lll}
\hline Criteria & Scale & Information \\
\hline & 1 & Violating the rules or not following work procedures more than 10 times \\
Activeness & 2 & Violating the rules or not following work procedures 7 to 10 times \\
& 3 & Violating the rules or not following work procedures 3 to 6 times \\
& 4 & Violating the rules or not following work procedures 1 to 2 times \\
& 5 & No rules violation and always follow work procedures \\
\hline
\end{tabular}

The anchor rating scale for the cooperation criteria is intended to determine employee performance in teamwork, shown in Table 14.

Table 14

Cooperation rating scale

\begin{tabular}{ccl}
\hline Criteria & Scale & \multicolumn{1}{c}{ Information } \\
\hline & 1 & Complaints from other employees for 7-10 times \\
Cooperation & 2 & Complaints from other employees for 4-6 times \\
& 3 & Complaints from other employees for 2-3 times \\
& 4 & Complaints from other employees for 1 time \\
& 5 & No complaint from other employees \\
\hline
\end{tabular}

The anchor rating scale for the emotional control criteria is intended to determine the employees' attitude at work, especially in controlling emotions so that there are no disputes with visitors or other employees, shown in Table 15.

Table 15

Emotional control rating

\begin{tabular}{ccl}
\hline Criteria & Scale & \multicolumn{1}{c}{ Information } \\
\hline & 1 & Having problems with visitors or with other employees more than 8 times \\
Emotional & 2 & Having problems with visitors or with other employees for 6-8 times \\
Control & 3 & Having problems with visitors or with other employees for 3-5 times \\
& 4 & Having problems with visitors or with other employees for 1-2 times \\
& 5 & No problems with visitors or other employees \\
\hline
\end{tabular}

The final calculation of the employee performance score (alternative) on each criterion is obtained by calculating the anchor score of the rating scale for each criterion then multiplying by the weighted score of the criteria. Formula 4 is used for calculating the alternative final score for each criterion.

$$
\text { nilai }=\sum(\text { Bobot Kriteria } x \text { Nilai Rating Scale })
$$

Table 16 shows an example of an employee assessment calculation based on the criteria weight and anchor criteria selected in the assessment process. 
Table 16

Example of employee appraisal

\begin{tabular}{|c|c|c|c|c|}
\hline Name & Criteria & Criteria Weight & $\begin{array}{c}\text { Anchor Rating } \\
\text { Scale }\end{array}$ & Score \\
\hline \multirow{5}{*}{$\begin{array}{c}\text { Kadek } \\
\text { Suparsa }\end{array}$} & Attendance & 0,10 & 3 & 0,30 \\
\hline & Service & 0,33 & 2 & 0,66 \\
\hline & Activeness & 0,23 & 3 & 0,69 \\
\hline & Cooperation & 0,13 & 2 & 0,26 \\
\hline & Emotional control & 0,20 & 2 & 0,40 \\
\hline \multicolumn{4}{|c|}{ Final Score } & 2,31 \\
\hline \multirow{6}{*}{$\begin{array}{c}\text { I Gede } \\
\text { Asmara }\end{array}$} & Attendance & 0,10 & 3 & 0,30 \\
\hline & Service & 0,33 & 2 & 0,66 \\
\hline & Activeness & 0,23 & 1 & 0,23 \\
\hline & Cooperation & 0,13 & 2 & 0,26 \\
\hline & Emotional Control & & 5 & 1,00 \\
\hline & \multicolumn{3}{|c|}{ Final Score } & 2,45 \\
\hline
\end{tabular}

The score in the Criteria Weight column refers to the score presented in Table 9. The column of the Anchor Rating Scale is based on the behavior (anchor) of each criterion. Each anchor has a predetermined rating scale from 1 to 5 . The score refers to the anchor score of each criterion listed in Table 10, Table 11, Table 12, Table 13, and Table 14. The score collum is the multiplication of the criterion weight score with the anchor. The final score is obtained from the sum of the scores in the Score column, according to Formula 3.

\section{Result and Discussion}

The development stage of the decision support system on employee assessment uses the PHP programming language and MySQL database. The implementation stage begins by discussing the user interface display (the decision support system on employee assessment interface uses the ANP method and the web-based Rating Scale. The initial login display for users is shown in Figure 3.

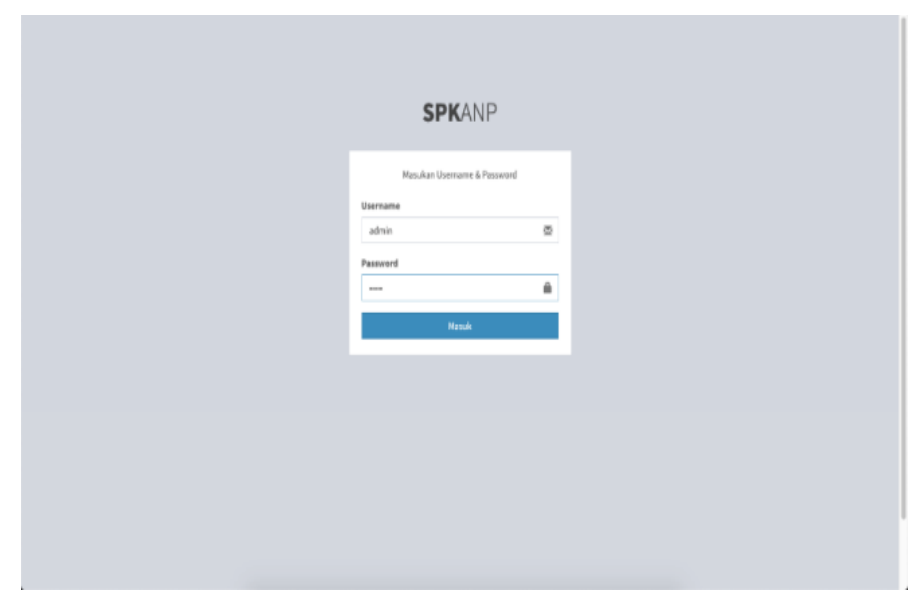

Fig 3. Admin Login View

The next view is the criteria page view that can be used to see the criteria used and the weighted score of each criterion, shown in Figure 4. 


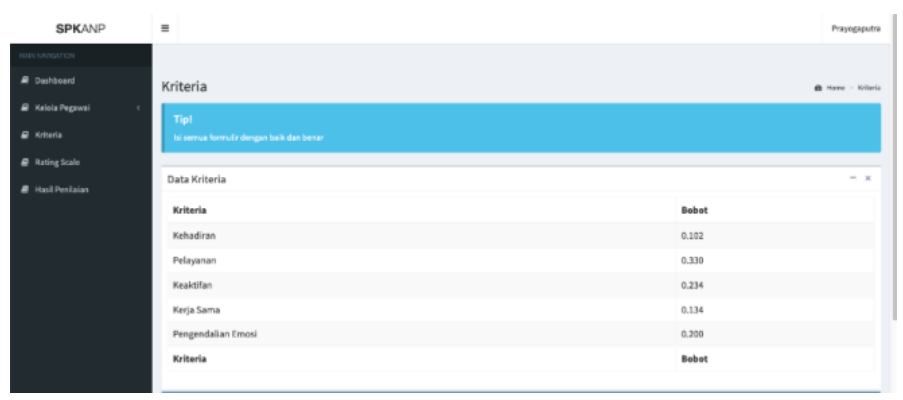

Fig 4. Criteria Page View

The rating scale page view is intended to provide alternative scores on each criterion scale, shown in Figure 5.

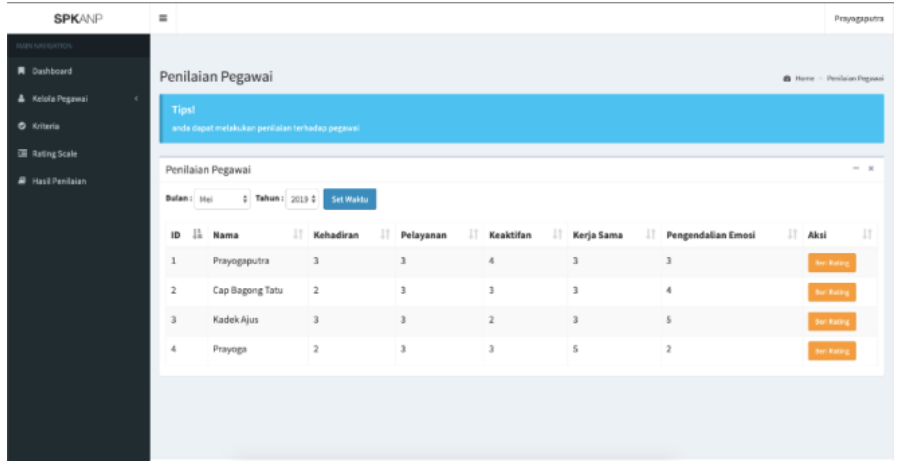

Fig 5. Rating Scale Page View

The rating scale process on page view is intended to describe each criterion of the rating scale, shown in Figure 6.

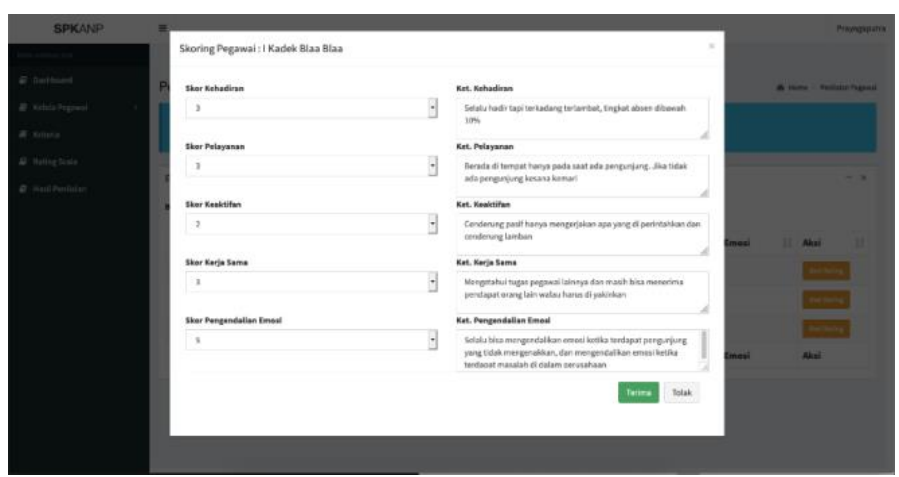

Fig 6. Rating Scale Process Page View

The next view is a process page view that displays the results of the employee assessment SPK calculation, the report page can be determined based on the selected selection period. The report page view is shown in Figure 7. 


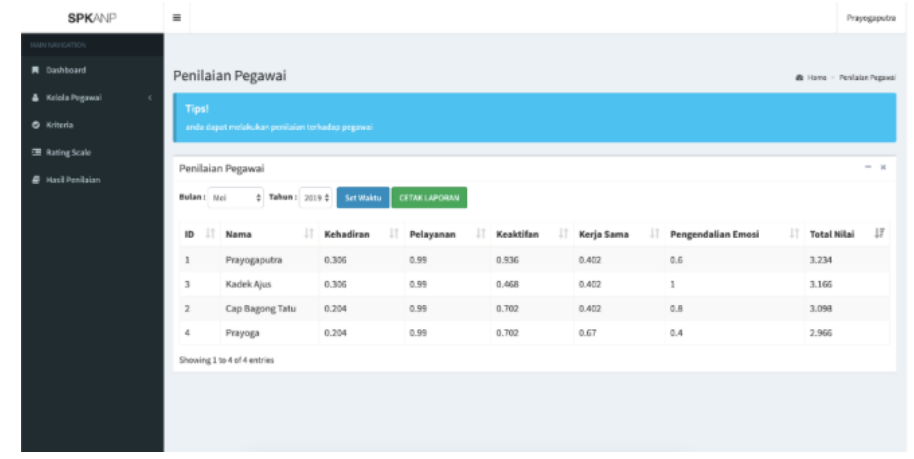

Fig 7. The Report Page View

Testing on the decision support system on employee assessment that has been built in this study is manual calculation testing with the system and user perceptual testing. In the test results, manual and system calculations are not much different, it is just different behind the comma, for example, Putu Usada's employees get a score of 4.96 whereas the system gets a score of 5 then Kadek Suparsa is calculated manually gets a score of 2.31 whereas the system gets a score of 2.336 then I Gede Asmara is calculated manually gets a score of 2.45 whereas the system gets a score of 2.468 then Ni Ketut Susmini gets a score of 0.99 manually, whereas the system gets a score of 1 and Anak Agung Darma Putra gets a score of 2.97 manually whereas the system gets a score of 3 . The difference between the results of manual and system assessments is calculated as an average score of 0.025 . The comparison of the results of manual and system calculations is shown in Table 17.

Table 17

The comparison of manual and system calculations

\begin{tabular}{lllll}
\hline No. & Employee & Manual Assessment Result & $\begin{array}{l}\text { System Assessment } \\
\text { Result }\end{array}$ & Different \\
\hline 1 & Putu Usada & 4,96 & 5 & 0,040 \\
2 & Kadek Suparsa & 2,31 & 2,336 & 0,026 \\
3 & I Gede Asmara & 2,45 & 2,468 & 0,018 \\
4 & Ni Ketut Susmini & 0,99 & 1 & 0,010 \\
5 & Anak Agung Darma Putra & 2,97 & 3 & 0,030 \\
\hline Difference Average & & & 0,025 \\
\hline
\end{tabular}

In user testing is done by giving a questionnaire to the manager of PT. Kupu-Kupu Taman Lestari as the system user. The questionnaire items were arranged based on the software quality factors by McCall. McCall's factor model classified all software requirements into 11 quality factors [17]. In this article, the factor category used is the product operation factor. The questionnaire uses an answer scale of Strongly Disagree (STS), Disagree (TS), Agree (S), and Strongly Agree (SS). The score for each answer from STS to SS is 1 to 4 . Each aspect is calculated as the average score of the results of the user questionnaire answers.

Based on user testing (Table 18), the result shows that correctness gets an average score of 3.5 with a percentage of $87.5 \%$ of the maximum score of 4 . Correctness shows the accuracy of the calculation process and the reports generated by the system. Reliability gets an average score of 3.67 with a percentage of $91.67 \%$. From the results of the reliability assessment, the system functionality has been achieved as needed. Integrity gets a score of 4 with a percentage of $100 \%$, this shows the level of data security on the system is achieved with the username and password features that are only owned by managers. Usability gets an average score of 3.33 with a percentage of $83.33 \%$. The results of the usability assessment indicate that the ease of use of the system has been achieved.

The testing results show the decision support system built meets user needs, displays information according to user input appropriately, is safe from unauthorized parties, and the system is easy to use.

A Decision Support System on Employee Assessment Using Analytical Network Process (ANP) and BARS Methods 
Table 18

User testing questionnaire results

\begin{tabular}{|c|c|c|c|c|}
\hline Aspect & Question Point & $\begin{array}{ll}\text { STS } & \text { TS } \\
(1) & (2)\end{array}$ & $\begin{array}{c}S \\
(3)\end{array}$ & $\begin{array}{l}\text { SS } \\
(4)\end{array}$ \\
\hline \multirow{4}{*}{ Correctness } & The system generates a corresponding value to manual calculations & & $\checkmark$ & \\
\hline & The system helps in the employee performance appraisal process & & & $\checkmark$ \\
\hline & $\begin{array}{l}\text { The application of BARS in the system can represent the standard of } \\
\text { employee performance appraisal at the company }\end{array}$ & & $\checkmark$ & \\
\hline & $\begin{array}{l}\text { The system generates employee assessment reports based on the } \\
\text { period }\end{array}$ & & & $\checkmark$ \\
\hline \multirow{3}{*}{ Reliability } & The information provided is accurate & & $\checkmark$ & \\
\hline & $\begin{array}{l}\text { The system displays the results of ANP and BARS processing according } \\
\text { to the input }\end{array}$ & & & $\checkmark$ \\
\hline & The system displays the final result in the form of a ranking & & & $\checkmark$ \\
\hline Integrity & The system can be accessed only by managers & & & $\checkmark$ \\
\hline \multirow{3}{*}{ Usability } & Attractive system display & & $\checkmark$ & \\
\hline & Easy management of employee data & & & \\
\hline & Input criteria using the ANP and BARS methods are easy to do & & $\checkmark$ & \\
\hline
\end{tabular}

\section{Conclusion}

In this study, a web-based decision support system on employee performance assessment with ANP and BARS methods has been built. There are 5 criterion used with service criteria as the criteria that have the highest priority weight, namely 0.33 . The alternative employees selected were 5 employees with the highest final score is Putu Usada with a score of 4.96 (Table 17). The system and manual test results show a small difference of 0.025 (Table 17) due to the difference in the numbers behind the comma. Perception testing of system users with the McCall model approach shows the system built to meet user needs displays information according to user input appropriately, is safe from unauthorized parties, and the system is easy to use. With this decision support system, it can provide benefits for the HR department in recording and evaluating employees for the next process. Suggestions for further developments are expected to be able to build features for dynamic criteria and anchor scale, and assessment data can be used as a reference in the criteria sensitivity analysis so that it can be an alternative decision in improving employee performance according to the criteria determined by the company.

\section{References}

[1] D. Chakraborty and W. Biswas, "Evaluating the impact of human resource planning programs in addressing the strategic goal of the firm," J. Adv. Manag. Res., 2019.

[2] S. Bag, L. C. Wood, S. K. Mangla, and S. Luthra, "Procurement 4.0 and its implications on business process performance in a circular economy," Resour. Conserv. Recycl., vol. 152, p. 104502, 2020.

[3] A. S. DeNisi and K. R. Murphy, "Performance appraisal and performance management: 100 years of progress?," J. Appl. Psychol., vol. 102, no. 3, p. 421, 2017.

[4] Ž. Stević and N. Brković, "A novel integrated FUCOM-MARCOS model for evaluation of human resources in a transport company," Logistics, vol. 4, no. 1, p. 4, 2020.

[5] H. Urbancová, K. Stachová, and Z. Stacho, "Using of performance appraisal methods in Czech and Slovak organisations," Qual. Innov. Prosper., vol. 21, no. 3, pp. 62-77, 2017, doi: 10.12776/QIP.V21I3.890.

[6] B. Bin Saeed, B. Afsar, S. Hafeez, I. Khan, M. Tahir, and M. A. Afridi, "Promoting employee's proenvironmental behavior through green human resource management practices," Corp. Soc. Responsib. Environ. Manag., vol. 26, no. 2, pp. 424-438, 2019.

[7] D. J. Schleicher, H. M. Baumann, D. W. Sullivan, P. E. Levy, D. C. Hargrove, and B. A. Barros-Rivera, "Putting the system into performance management systems: A review and agenda for performance management research," J. Manage., vol. 44, no. 6, pp. 2209-2245, 2018.

[8] W. Alhazzani et al., "Surviving Sepsis Campaign: guidelines on the management of critically ill adults with Coronavirus Disease 2019 (COVID-19)," Intensive Care Med., vol. 46, no. 5, pp. 854-887, 2020.

[9] P. Tambe, P. Cappelli, and V. Yakubovich, "Artificial intelligence in human resources management: Challenges 
and a path forward," Calif. Manage. Rev., vol. 61, no. 4, pp. 15-42, 2019

[10] W. Wang, Y. Cui, Y. Luo, Z. Li, and J. Tan, "Web-based decision support system for canal irrigation management," Comput. Electron. Agric., vol. 161, pp. 312-321, 2019.

[11] R. Septifani, P. Deoranto, and T. W. Armanda, "Employee Performance Assessment Using Analytical Network Process and Rating Scale," J. Tek. Ind., vol. 21, no. 1, p. 70, 2020, doi: 10.22219/jtiumm.vol21.no1.70-79.

[12] Anwar, "Employee Performance Appraisal Analysis with Analytic Network Process (ANP) and Rating Scale Method in Baitul Mall Lhokseumawe," IOP Conf. Ser. Mater. Sci. Eng., vol. 505, no. 1, 2019, doi: 10.1088/1757899X/505/1/012065.

[13] D. M. Klieger, H. J. Kell, S. Rikoon, K. N. Burkander, J. L. Bochenek, and J. R. Shore, "Development of the Behaviorally Anchored Rating Scales for the Skills Demonstration and Progression Guide," ETS Res. Rep. Ser., vol. 2018, no. 1, 2018, doi: 10.1002/ets2.12210.

[14] E. D. Santoso, A. Fathoni, and L. B. Hasiholan, "Development of Employee Performance Appraisal of Honda Semarang Service Center," J. Manage., vol. 4, no. 4, 2018.

[15] M. Reisi, A. Afzali, and L. Aye, "Applications of analytical hierarchy process (AHP) and analytical network process (ANP) for industrial site selections in Isfahan, Iran," Environ. Earth Sci., vol. 77, no. 14, p. 0, 2018, doi: 10.1007/s12665-018-7702-1.

[16] M. Abdel-Basset, A. Atef, and F. Smarandache, "A hybrid Neutrosophic multiple criteria group decision making approach for project selection,” Cogn. Syst. Res., vol. 57, pp. 216-227, 2019.

[17] Meiryani, P. Siagian, R. A. A. W. Puspokusumo, and Lusianah, "Decision making and management information systems," J. Crit. Rev., vol. 7, no. 7, pp. 320-325, 2020, doi: 10.31838/jcr.07.07.52.

[18] Z. Zhai, J. F. Martínez, V. Beltran, and N. L. Martínez, "Decision support systems for agriculture 4.0: Survey and challenges," Comput. Electron. Agric., vol. 170, p. 105256, 2020.

[19] D. J. Power, "Computerized decision support case study research: concepts and suggestions," in Real-World Decision Support Systems, Springer, 2016, pp. 1-13.

[20] M. Shameem, R. R. Kumar, M. Nadeem, and A. A. Khan, "Taxonomical classification of barriers for scaling agile methods in global software development environment using fuzzy analytic hierarchy process," Appl. Soft Comput., vol. 90, p. 106122, 2020.

[21] O. M. Joffre, P. M. Poortvliet, and L. Klerkx, "To cluster or not to cluster farmers? Influences on network interactions, risk perceptions, and adoption of aquaculture practices," Agric. Syst., vol. 173, pp. 151-160, 2019.

[22] E. Mu, O. Cooper, and M. Peasley, "Best practices in Analytic Network Process studies," Expert Syst. Appl., 2020, doi: 10.1016/j.eswa.2020.113536.

[23] N. Kadoić, N. B. Ređep, and B. Divjak, "Decision making with the analytic network process," 2017, doi: 10.1007/0-387-33987-6.

[24] H. J. Kell, M. P. Martin-Raugh, L. M. Carney, P. A. Inglese, L. Chen, and G. Feng, "Exploring Methods for Developing Behaviorally Anchored Rating Scales for Evaluating Structured Interview Performance," ETS Res. Rep. Ser., vol. 2017, no. 1, pp. 1-26, 2017, doi: 10.1002/ets2.12152. 